\title{
ANALISIS DAN IDENTIFIKASI STATUS MUTU AIR TANAH DI KOTA SINGKAWANG STUDI KASUS KECAMATAN SINGKAWANG UTARA
}

\author{
Asmi Nur Aisyah ${ }^{1)}$ Kiki Prio Utomo ${ }^{1)}$ Dian Rahayu Jati ${ }^{1)}$ \\ 1)Program Studi Teknik Lingkungan Jurusan Teknik Sipil Fakultas Teknik Universitas Tanjungpura, Pontianak \\ Email: asminuraisyah_03@gmail.com
}

\begin{abstract}
ABSTRAK
Keberadaan air baku sebagai sumber air bersih memiliki peranan penting dalam meningkatkan kualitas hidup masyarakat di suatu daerah. Air baku yang dapat dijadikan sebagai sumber air bersih adalah air permukaan, air hujan maupun air tanah. Singkawang Utara merupkan salah satu wilayah yang masyarakatnya masih memanfaatkan air tanah sebagai air baku. Hasil pengamatan secara organoleptik yang pernah dilakukan pada Februari 2016 lalu terhadap kualitas air tanah yang digunakan oleh masyarakat setempat secara fisik terlihat berwarna kuning kecokelatan, berbau dan menyebabkan kulit menjadi kering bahkan alergi. Berdasarkan hal tersebut, peneliti mencoba mengkaji kualitas air sumur dangkal di Kecamatan Singkawang Utara. Tujuan dari penelitian adalah menganalisis kualitas air tanah dangkal secara fisika, kimia, dan mikrobiologi berdasarkan Baku Mutu Air Kelas I dari Peraturan Pemerintah No. 82 Tahun 2001 dan menetukan status mutu kualitas air sumur dangkal dengan menggunakan Metode Storet. Lokasi penelitian dilakukan di 7 titik di Kecamatan Singkawang Utara, masing-masing titik mewakili kawasan administratif (kelurahan). Hasil penelitian menunjukkan bahwa analisis pengujian sampel air tanah dangkal di Wilayah Singkawang Utara yang melebihi baku mutu adalah parameter Fisika yaitu TDS dengan nilai tertinggi $1530 \mathrm{mg} / \mathrm{L}$ pada titik 2 disebabkan karena kondisi sumur yang terletak diantara dua (2) buah cubluk dengan jarak $4 \mathrm{~m}$ dan $6 \mathrm{~m}$ serta selokan yang berjarak $4 \mathrm{~m}$. Parameter Kimia yaitu Besi ( $\mathrm{Fe}$ ) dengan nilai tertinggi 4,0 mg/L pada titik 6, Mangan (Mn) dengan nilai $2,3 \mathrm{mg} / \mathrm{L}$ pada titik 7, keberadaan unsur dari parameter tersebut disebabkan karena adanya pengaruh dari kondisi tanah yang terdapat di Wilayah Singkawang Utara, Nitrat $\left(\mathrm{NO}_{3}\right)$ dengan nilai 75,3 pada titik 7 disebabkan karena jarak antara sumur dengan cubluk yang relatif dekat yaitu $8,5 \mathrm{~m}$ dan adanya ativitas dari peternakan kambing dengan jarak $4 \mathrm{~m}$. Parameter biologi yaitu Total Coliform dengan nilai MPN 1100 pada titik 1, 2, 6 dan 7 karena kondisi sumur pada titik 1, 2, 6 dan 7 berdasarkan konstruksi tidak dilengkapi dengan penutup sumur, kondisi jarak terhadap cubluk yang relatif dekat yaitu berjarak $\leq 10 \mathrm{~m}$, adanya sumber pencemar lain berupa tumpukan sampah, selokan, dan kadang ternak. Identifikasi status mutu air tanah di Wilayah Singkawang Utara termasuk dalam Kelas B (cemar ringan) dengan skor -7,9. Faktor yang mempengaruhi pencemaran tersebut berasal dari faktor alami maupun non alami. Faktor alami berasal dari kondisi geologi wilayah setempat, sedangkan faktor non alami berasal dari aktivitas yang terdapat di sekitar sumur.
\end{abstract}

Kata Kunci : Kualitas Air Tanah Dangkal, Metode Storet, Singkawang Utara

\section{ABSTRACT}

The existence of raw water as a source of clean water has an important role in improving the quality of life in an area. The raw water can be used as a source of clean water is surface water, rain water and ground water. North Singkawang is one of the areas where people still use ground water as raw water. The organoleptic observation conducted in February 2016 on the quality of groundwater used by local communities resulted that physically was a yellow-brown colored, odorless and causes the skin to become dry and even allergies. Based on this, the researcher tried to assess the water quality of shallow wells in the North Singkawang District. The purpose of the study are to analyze the quality of shallow groundwater physically, chemically, and microbiologically based on Water Quality Standards Class I of the Government Regulation No. 82 Year 2001, and to determine the status of water quality of shallow wells by using StoretMethod. Locations of the research are on 7 points in North Singkwang District, where each point represent each of administrative district (villages) in North Singkawang District. The results show that the analysis of test samples of shallow ground water in the North Singkawang area whichexceeded 
the quality standard are a physical parameter namely TDS with the highest value of $1530 \mathrm{mg} / \mathrm{l}$ at point 2 due to the condition of the well which is located between two (2) units of latrine with a distance of $4 \mathrm{~m}$ and $6 \mathrm{~m}$ and a sewers within $4 \mathrm{~m}$. Chemical parameters namely iron (Fe) with the highest value of $4.0 \mathrm{mg} / \mathrm{l}$ at point 6 , Manganese $(\mathrm{Mn})$ with a value of $2.3 \mathrm{mg} / \mathrm{l}$ at the point 7 , where traces of these elementparameters due to the influence of local soil conditions in within the area, Nitrate $\left(\mathrm{NO}_{3}\right)$ with a value of 75.3 at point 7 ,caused by the distance between the wells withlatrine is relatively close at $8.5 \mathrm{~m}$ and the activity of a goat farm with a distance of $4 \mathrm{~m}$. Biological parameters: Total Coliform with a value of 1100 MPN at point 1, 2, 6 and 7 because the condition of the well constructions at point 1, 2, 6 and 7 are not equipped with the well cover, and the conditions of nearest latrine is relatively close which iswithin $\leq 10 \mathrm{~m}$, the presence of other pollutant sources in the form of a pile of garbage, sewer, and stockyard. Identification of the status of groundwater quality in North Singkawang District is on Class B (lightly contaminated) with a score of -7.9. Factors affecting the pollution came from natural and non-natural factors. Natural factor attained from the geological conditions of the local area, while the non-natural attained from activities surrounding the well.

Keywords: Shallow Ground Water Quality, Storet Method, North Singkawang

\section{- PENDAHULUAN}

Keberadaan air baku sebagai sumber air bersih memiliki peranan penting dalam meningkatkan kualitas hidup masyarakat di suatu daerah. Air baku yang dapat dikategorikan sebagai sumber air bersih adalah air yang dapat memenuhi syarat baik secara fisik, kimia, dan mikroiologi berdasarkan baku mutu air Kelas I Peraturan Pemerintah Nomor 82 Tahun 2001 tentang Pengelolaan Kualitas Air dan Pengendalian Pencemaran. Air baku yang dapat dijadikan sebagai sumber air bersih adalah air permukaan, air hujan mau pun air tanah.

Masyarakat di Singkawang Utara masih memanfaatkan air tanah untuk memenuhi kebutuhan sehari-hari seperti Mandi Cuci dan Kakus (MCK). Hasil pengamatan secara organoleptik yang pernah dilakukan oleh Tim Teknik Lingkungan pada Februari 2016 terhadap kualitas air sumur yang digunakan oleh masyarakat di Kelurahan Naram secara fisik terlihat berwarna keruh, dan berbau, sementara kondisi kualitas air di Kecamatan Setapuk Besar terlihat berwarna kuning kecoklatan, sedikit berbau dan menyebabkan kulit menjadi kering apabila digunakan untuk mandi. Menurut Mathelumual (2007) faktor-faktor yang dapat mempengaruhi kualitas air tanah di suatu wilayah karena adanya pengaruh dari material (tanah dan batuan) yang mengandung atau yang dilewati air tanah tersebut, jenis aliran, dan proses perubahan akibat pencemaran yang berasal dari aktivitas masyarakat setempat.

Sebuah upaya yang dapat dilakukan untuk mengontrol kondisi suatu lingkungan adalah dengan melakukan pemantauan kualitas air pada waktu tertentu. Berdasarkan kondisi tersebut, maka diperlukan adanya pengujian kualitas air tanah baik secara fisik, kimia maupun mikrobiologi di Kecamatan Singkawang Utara. Hasil pengujian kualitas air tanah tersebut dilanjutkan dengan mengidentifikasi status mutu air tanah dengan menggunakan Metode Storet. Keunggulan Metode Storet adalah dapat menunjukan parameter kualitas air yang paling mempengaruhi dari kondisi air tersebut sehingga dapat diklasifikasikan tingkat pencemaran dari air tanah yang digunakan oleh masyarakat di Wilayah Singkawang Utara.

\section{- METOdOLOGI PENELITIAN}

$>$ Lokasi dan Waktu Penelitian

Teknik pengambilan sampel) yang dilakukan adalah Teknik Purposive Sampling yaitu merupakan teknik pengambilan sampel secara sengaja dengan pertimbangan tertentu. Peneliti membagi kawasan penelitian menjadi tujuh (7) titik lokasi berdasarkan pembagian wilayah administratif (kelurahan). Pengambilan sampel dilakukan pada setiap kelurahan berdasarkan kriteria tertentu yaitu sumur yang dipilih adalah sumur yang masih digunakan masyarakat terutama untuk MCK, pemilihan sumur berdasarkan jarak sumur dengan sumber pencemar yaitu $\leq 15 \mathrm{~m}$ (area pertanian, tumpukan sampah, kandang ternak, selokan / parit, saluran pembuangan rumah tangga, cubluk). 


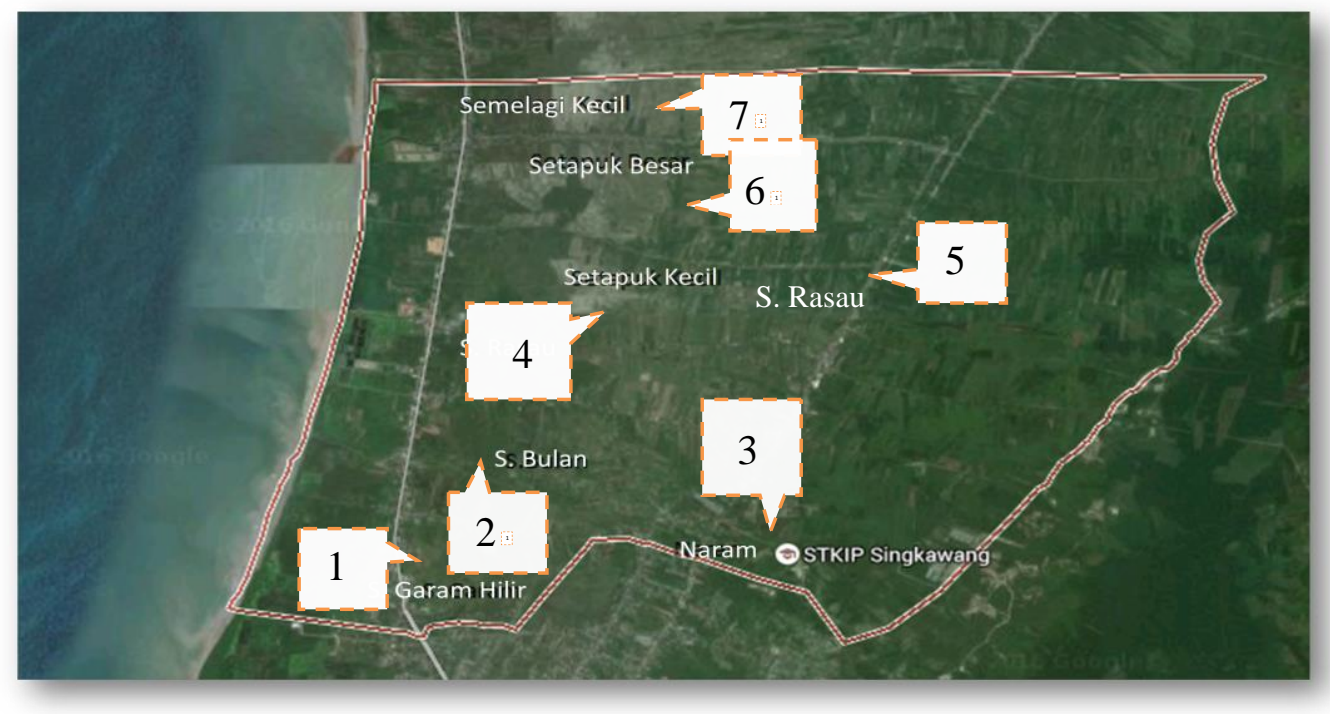

Gambar 1. Lokasi pengambilan sampel di Kecamatan Singkawang Utara

Pengambilan sampel dilaksanakan pada Hari Minggu, 24 September 2016 pukul 09.00 pagi 14.00 siang. Adapun parameter uji yang dianalisa dalam penelitian ini adalah parameter fisik yaitu Suhu dan TDS, parameter kimia yaitu pH, Besi, Mangan, Nitrit dan Nitrat, sedangkan parameter Biologi yaitu Total Coliform. Pengujian suhu dan $\mathrm{pH}$ dilakukan secara in-situ (di lokasi pengambilan sampel), sedangkan pengujian lainnya dilaksanakan secara ex-situ di Laboratorium Kualitas dan Kesehatan Lahan Fakultas Pertanian Universitas Tanjungpura untuk parameter fisika dan kimia, sedangkan parameter mikrobiologi akan dilakukan pengujian di Laboratorium Mikrobiologi Prodi Teknik Lingkungan Fakultas Teknik Universitas Tanjungpura.

\section{$>$ Alat dan Bahan Penelitian}

Alat-alat yang digunakan dalam penelitian ini terbagi atas 2 (dua) yaitu alat yang digunakan pada saat di lapangan dan alat yang digunakan pada saat dilakukan pengujian sampel di Laboratorium. Alat-alat yang digunakan di lapangan adalah alat tulis, aluminium foil, botol sampel ukuran 1500 dan $100 \mathrm{~mL}$ (beserta tutupnya yang sudah disterilkan), jerigen, cool box, kertas label, meteran, plastik, plastik wraping, $\mathrm{pH}$ meter, termometer, tali dan tissu. Sementara itu, alat-alat yang digunakan pada saat pengujian di laboratorium adalah alat tulis, autoclave, bunsen, cawan petri, gelas ukur, jarum ose, kertas label, rak tabung reaksi, tabung reaksi, pipet volume, tabung erlenmeyer, spatula, tabung durham, dan tissu.

Bahan-bahan yang digunakan adalah akuades, alkohol $70 \%$, sampel air sumur, spiritus, media BGLB (Briliant Green Lactose Briliant Broth), media LB (Lactose Broth), dan media EMB (Eosin Methylen Blue).

\section{$>$ Prosedur Pengambilan Sampel dan Pengujian Mikrobiologi}

Prosedur dalam pengambilan sampel air khususnya untuk pengujian parameter fisika, kimia dan biologi mengacu pada SNI 6989.58 : 2008 Tentang Metode Pengambilan Contoh Air Tanah. Sementara itu, prosedur dalam melakukan pengujian mikrobiologi mengacu SNI 01-2332.1-2006 tentang Penentuan Coliform dan Eschericia Coli dan mengacu pada metode MPN berdasaran jurnal Sutton (2010) dalam jurnal The Most Probable Number Method and Its Uses in Enumeration, Qualification, and Validation.

\section{$>$ Analisa Data}

Metode analisa data yang digunakan dalam penelitian ini adalah dengan metode Deskriptif. Deskriptif merupakan metode untuk menganalisis hasil penelitian dari data yang didapat terhadap peraturan mengenai baku mutu kualitas air yang ditetapkan berdasarkan Peraturan Pemerintah Nomor 82 Tahun 2001 Tentang Pengelolaan Kualitas Air dan Pengendalian Pencemaran Air Kelas I. Kemudian dilanjutkan dengan membandingkan data hasil pengukuran baku mutu dengan menggunakan Metode Storet berdasarkan kalsifikasi nilai yang ditetapkan oleh US-EPA (Environmental Protection Agency) dalam Keputusan Menteri Lingkungan Hidup No. 115 Tahun 2003. 
Metode Storet merupakan salah satu metoda untuk penentuan status mutu air yang umum digunakan. Dengan metoda Storet ini dapat diketahui parameter-parameter yang telah memenuhi atau melampaui baku mutu air. Secara prinsip metoda Storet adalah membandingkan antara data kualitas air dengan baku mutu air yang disesuaikan dengan peruntukan guna menentukan status mutu air. Cara untuk menentukan status mutu air adalah dengan menggunakan sistem nilai dari US-EPA dengan mengklasifikasikan mutu air dalam empat kelas, yaitu :
(1) Kelas A : baik sekali,
(2) Kelas B : baik,
(3) Kelas C : sedang,
(4) Kelas D : buruk,
total skor $=0 \quad=*$ memenuhi baku mutu
total skor= $-1 \mathrm{~s} / \mathrm{d}-10 \quad=$ cemar ringan
total skor $=-11 \mathrm{~s} / \mathrm{d}-30 \quad=$ cemar sedang
total skor $\geq-31 \quad=$ cemar berat

Dengan metoda Storet ini dapat diketahui parameter-parameter yang telah memenuhi atau melampaui baku mutu air. Secara prinsip metoda Storet adalah membandingkan antara data kualitas air dengan baku mutu air yang disesuaikan dengan peruntukan guna menentukan status mutu air.

\section{- HASIL DAN PEMBAHASAN}

\section{Analisis Kualitas Air}

Air tanah digunakan oleh masyarakat setempat untuk memenuhi kebutuhan sehari-hari seperti MCK (Mandi, Cuci dan Kakus). Sehingga, analisis yang dilakukan terhadap air tanah mengacu pada Peraturan Pemerintah Nomor 82 Tahun 2001 baku mutu air Kelas I, yaitu air yang dapat digunakan sebagai air baku dan dapat menjadi tolak ukur bagi baku mutu air kelas lain. Adapun hasil analisis kualitas air tanah di Kecamatan Singkawang Utara dapat dilihat pada Tabel 1.

Tabel 1. Hasil Analisis Kualitas Air Tanah di Kec. Singkawang Utara

\begin{tabular}{|c|c|c|c|c|c|c|c|c|c|}
\hline \multirow{2}{*}{ Parameter } & \multirow{2}{*}{ Satuan } & \multirow{2}{*}{$\begin{array}{c}\text { Mutu } \\
\text { Air } \\
\text { Kelas I }\end{array}$} & \multicolumn{7}{|c|}{ Hasil Pengukuran } \\
\hline & & & S1 & S2 & S3 & S4 & S5 & S6 & S7 \\
\hline \multicolumn{10}{|l|}{ Fisika } \\
\hline & & Deviasi & & & & & & & \\
\hline Temperatur & ${ }^{\circ} \mathrm{C}$ & 3 & 28 & 27 & 29 & 29 & 29 & 28 & 29 \\
\hline TDS & $\mathrm{mg} / \mathrm{L}$ & 1000 & 905 & *1530 & 52,4 & 41,9 & 45,6 & 188,8 & 221 \\
\hline \multicolumn{10}{|l|}{ Kimia } \\
\hline $\mathrm{pH}$ & $\mathrm{mg} / \mathrm{L}$ & $6-9^{\prime}$ & 7 & 7,2 & 6,5 & 7 & 6,4 & 6,5 & 6,5 \\
\hline Besi (Fe) & $\mathrm{mg} / \mathrm{L}$ & 0,3 & $* 0,8$ & $* 1,0$ & $* 2,6$ & $* 3,0$ & $* 1,1$ & $* 4,1$ & $* 3,0$ \\
\hline \multicolumn{10}{|l|}{ Mangan } \\
\hline (Mn) & $\mathrm{mg} / \mathrm{L}$ & 0,1 & $* 1,8$ & $* 0,9$ & $* 0,2$ & $* 0,4$ & $* 0,1$ & $* 1,8$ & $* 2,3$ \\
\hline Nitrit ( $\left.\mathrm{No}_{2}\right)$ & $\mathrm{mg} / \mathrm{L}$ & 0,06 & 0,004 & 0,004 & 0,002 & 0,003 & 0,003 & 0,003 & 0,004 \\
\hline Nitrat ( $\left.\mathrm{NO}_{3}\right)$ & $\mathrm{mg} / \mathrm{L}$ & 10 & $* 61,4$ & $* 36,7$ & $* 60,9$ & $* 50,6$ & $* 70,6$ & $* 59,7$ & $* 75,3$ \\
\hline \multicolumn{10}{|l|}{ Biologi } \\
\hline Total & Jumlah/100 & & & & & & & & \\
\hline Coliform & $\mathrm{ml}$ & 1000 & $* 1100$ & $* 1100$ & 460 & 240 & 150 & $* 1100$ & $* 1100$ \\
\hline
\end{tabular}

*melebihi baku mutu

Berdasarkan Tabel 1. dapat dilihat bahwa, diantara 8 parameter uji yang digunakan sebagai pengukuran kualitas air tanah di Kecamatan Singkawang Utara, terdapat 5 parameter kualitas air yang melebihi Peraturan Pemerintah Nomor 82 Tahun 2001 sebagai baku mutu air bersih Kelas I. Parameter tersebut adalah TDS, Besi, Mangan, Nitrat dan Total Coliform. Sementara untuk nilai temperatur, $\mathrm{pH}$ dan Nitrit masih memenuhi syarat dari kualitas air bersih Kelas I. Nilai TDS yang melebihi baku mutu terdapat pada titik 2 dengan nilai 1530. Nilai Besi, Mangan dan Nitrat melebihi baku mutu pada semua sampel. Sedangkan nilai Total Coliform yang melebihi baku mutu terdapat pada sampel air sumur 1, 2, 6 dan 7.

\section{a. Total Dissolved Solid (TDS)}

Berdasarkan hasil analisis pada Tabel 1. dapat dilihat bahwa kadar TDS pada sampel berkisar $41,9 \mathrm{mg} / \mathrm{L}$ sampai dengan $1530 \mathrm{mg} / \mathrm{L}$. Apabila dibandingkan dengan baku mutu air bersih Kelas I, nilai TDS maksimal yang diizinkan adalah sebesar $1000 \mathrm{mg} / \mathrm{L}$ sehingga kadar TDS pada sampel 
masih berada di bawah baku mutu air. Namun pada titik 2 memiliki nilai TDS yang melebihi baku mutu yaitu $1530 \mathrm{mg} / \mathrm{L}$. Tingginya kadar TDS pada sampel titik 2 diduga dipengaruhi oleh kondisi sumur yang terletak diantara dua (2) buah cubluk dengan jarak $4 \mathrm{~m}$ dan $6 \mathrm{~m}$ sehingga banyaknya kandungan organik yang meresap ke dalam tanah akibat adanya rembesan air ke dalam aliran air tanah sumur tersebut. Selain itu, adanya rembesan dari air selokan terhadap sumur akibat terjadinya hujan sehari sebelum pengambilan sampel sehingga adanya akumulasi dari air rembesan cubluk dan selokan yang berada di sekitar sumur.

Air selokan yang berada di sekitar sumur pada titik 2 adalah berasal dari air buangan dari aktivitas domestik (grey water) yaitu berupa air dari hasil cucian yang bercampur dengan air hujan. Dekatnya jarak selokan terhadap sumur mempengaruhi kondisi air sumur. Hal tersebut sesuai dengan penelitian yang dilakukan oleh Jatmiko (2007) bahwa lokasi selokan yang berjarak $\leq 25 \mathrm{~m}$ akan mempengaruhi kondisi air sumur terutama untuk parameter TDS. Hal ini disebabkan karena air selokan banyak mengandung unsur-unsur organik, anorganik, endapan dan bahan buangan padat lainnya yang terlarut.

Berbeda halnya dengan nilai TDS di titik 6 yang memiliki jarak $8 \mathrm{~m}$ dari cubluk dan $6,8 \mathrm{~m}$ dari selokan, begitu halnya pada titik 5 dan 7 yang memiliki sumber pencemar lain berupa kandang ternak namun memiliki nilai TDS yang masih berada di bawah baku mutu air bersih. Sehingga diduga penyebab utama tingginya nilai TDS pada titik 2 disebabkan oleh rembesan dari kedua buah cubluk dan selokan yang terakumulasi ke dalam air tanah yang memiliki jarak lebih dekat dari kondisi sumber pencemar pada titik 6. Air selokan tersebut tercampur oleh limbah domestik (grey water) yang berasal dari aktivitas masyarakat setempat sehingga banyaknya kandungan organik dan an organik dan terakumulasi ke dalam air sumur.

Nilai TDS yang hampir melebihi baku mutu air baku Kelas I terdapat pada sampel titik 1 dengan nilai $905 \mathrm{mg} / \mathrm{L}$. Pada titik 1, jarak antara sumur terhadap cubluk adalah $8 \mathrm{~m}$ dan jaraknya terhadap sumber pencemar lain adalah keberadaan timbunan sampah yang berjarak $4 \mathrm{~m}$ dari sumur. Meskipun masih berada di bawah baku mutu air, namun tingginya kadar TDS pada sampel di titik 1 diduga berasal dari rembesan timbunan sampah yang berjarak $\pm 4 \mathrm{~m}$ dari sumur

\section{b. Besi (Fe)}

Besi atau ferrum (Fe) merupakan metal berwarna putih keperakan yang pada umumnya sukar larut di dalam tanah. Unsur besi terdapat hampir pada semua air tanah (Kurniawan, 2014). Berdasarkan hasil penelitian pada Tabel 1. menunjukkan bahwa semua sampel yang diuji memiliki kandungan besi melewati baku mutu air Kelas I dengan kadar tertinggi kandungan Besi pada sampel titik 6 dengan nilai 4,1 mg/L. Tingginya kandungan Besi yang terdapat pada sampel diduga karena adanya faktor alami dikarenakan tidak adanya sektor industri ataupun aktivitas yang dapat menimbulkan limbah maupun menyumbang kandungan Besi ke dalam air tanah. Faktor alami tersebut dihasilkan oleh jenis tanah dan batuan yang menyusun wilayah tersebut.

Menurut Sudadi (2003) sebagian besar unsur Besi terdapat pada tanah yang mengandung batuan sedimen yang mengandung oksida besi, karbonat dan sulfida. Wilayah Singkawang Utara merupakan salah satu wilayah yang memiliki jenis tanah aluvial dengan batuan penyusun berupa sedimen yang banyak mengandung unsur mineral (Dinas Pertambangan Provinsi, 2016) sehingga menjadi faktor penyebab tingginya kandungan besi yang terdapat dalam air tanah di wilayah tersebut. Kadar Besi yang tinggi dapat menyebabkan timbulnya karat pada peralatan logam, serta dapat memudarkan warna pada pakaian, selain itu air yang memiliki kadar besi lebih dari $1 \mathrm{mg} / \mathrm{L}$ dapat menimbulkan gangguan kesehatan berupa iritasi pada mata maupun kulit (Joko, 2010 dalam Purwonugroho, 2013).

\section{c. Mangan (Mn)}

Mangan merupakan salah satu logam yang banyak ditemukan bersama dengan unsur besi. Kandungan Mangan di bumi sekitar 1060 ppm dan sekitar 61-1010 ppm yang terdapat di tanah (Sudadi, 2003). Berdasarkan Tabel 1. terlihat bahwa semua sampel yang diuji memiliki kadar Mn melebihi baku mutu yang ditetapkan. Kandungan Mangan yang diizinkan menurut baku mutu air bersih Kelas I PP No. 82 tahun 2001 adalah 0,1 mg/, sementara itu, kandungan Mangan pada sampel di setiap titik memiliki nilai melebihi baku mutu dengan nilai yang bervariasi yaitu dimulai dari 0,1-2,3 mg/L. Sudadi (2003) menyebutkan pada kondisi air yang normal (terutama untuk air permukaan) nilai Mangan dalam suatu perairan umumnya mengandung 0,02 $\mathrm{mg} / \mathrm{L}$. Sehingga diduga tingginya kandungan $\mathrm{Mn}$ yang terdapat di setiap sampel disebabkan oleh faktor alami. 
Faktor alami tersebut dapat berasal dari jenis tanah dan batuan penyusun daerah tersebut. Tinggi rendahnya kadar Mangan dalam air tanah dipengaruhi oleh kandungan oksigen yang terdapat dalam air tersebut, sedikitnya kandungan oksigen yang terdapat di dalam air tanah sehingga membentuk oksida yang menyebabkan unsur Mangan semakin terendap dan merubah warna air. Sama halnya dengan kandungan Besi, tingginya kandungan Mangan dalam air tanah pada semua sampel disebabkan oleh faktor alami yang berasal dari jenis batuan penyusunnya. Kandungan yang terdapat dalam batuan penyusun berupa sedimen tersebut salah satunya adalah Mangan yang dilepas dari batuan tersebut karena proses pelapukan dengan hasil mineral sekunder terutama pyrolusit $\left(\mathrm{MnO}_{2}\right)$ dan manganit $(\mathrm{MnO}(\mathrm{OH}))$.

\section{d. Nitrit $\left(\mathrm{NO}_{2}\right)$ dan Nitrat $\left(\mathrm{NO}_{3}\right)$}

Berdasarkan hasil pengujian dari Tabel 1. menunjukkan kadar $\mathrm{NO}_{2}$ pada semua sampel masih berada di bawah baku mutu air Kelas I, yaitu memiliki rentang nilai 0,002-0,004 mg/L. Kondisi tersebut tidak mempengaruhi kualitas pada air tanah yang dijadikan sampel sesuai pendapat yang dikemukakan oleh Novotny dan Olem (1994) dalam Jatmiko (2009) bahwa $\mathrm{NO}_{2}$ merupakan senyawa yang labil. $\mathrm{NO}_{2}$ merupakan proses oksidasi antara amoniak dan $\mathrm{NO}_{3}$ sehingga nilai kandungan $\mathrm{NO}_{2}$ tersebut jarang berada diatas baku mutu, hal tersebut karena $\mathrm{NO}_{2}$ merupakan senyawa yang mudah untuk dioksidasikan.

Kandungan $\mathrm{NO}_{3}$ tertinggi berada pada sampel di titik ke 7 dengan nilai 75,3 mg/L, tingginya nilai $\mathrm{NO}_{3}$ tersebut selain dipengaruhi oleh keberadaan cubluk yang relatif dekat. Selain itu, tingginya kadar $\mathrm{NO}_{3}$ juga dipengaruhi kontaminasi dari limbah yang dihasilkan oleh hewan ternak (kambing) yang berasal dari kandang ternak dengan jarak $4 \mathrm{~m}$ dari sumur. Kondisi sumur pada titik 7 berasal dari tanah sehingga memungkinkan mudahnya polutan dari sumber kontaminan tersebut meresap dan merembes ke dalam tanah sehingga dapat mempengaruhi air tanah. Begitu halnya dengan kandungan $\mathrm{NO}_{3}$ pada sampel 5 dengan nilai yang tidak jauh berbeda pada sampel titik 7 yaitu 70,6 mg/L dengan jarak $1 \mathrm{~m}$ dari kandang ternak (ayam). Namun, konstruksi sumur di titik 5 terbuat dari semen yang dilengkapi dengan penutup sehingga dapat meminimalisir masuknya kontaminan yang berasal dari kandang hewan ternak di sekitar sumur tersebut.

Titik 2 memiliki kandungan $\mathrm{NO}_{3}$ dalam air tanah dengan nilai $36,7 \mathrm{mg} / \mathrm{l}$, yang dipengaruhi oleh keberadaan cubluk dengan jarak $4 \mathrm{~m}$ dan $6 \mathrm{~m}$ dan selokan yang berjarak $4 \mathrm{~m}$. Pada titik 1 , kandungan $\mathrm{NO}_{3}$ adalah $61,4 \mathrm{mg} / \mathrm{l}$ hal tersebut diduga adanya pengaruh dari cubluk dengan jarak 8 $\mathrm{m}$ dan 3,5 m dari tumpukan sampah. Selain karena konstruksi sumur tersebut berasal dari tanah, juga disebabkan karena sumur tersebut tidak dilengkapi dengan penutup dan bibir sumur sehingga mengakibatkan adanya rembesan air hujan yang tercampur kedalam air tumpukan sampah dan melimpas ke dalam sumur. Menurut Steenvorden (1989) dalam Ompusunggu (2009) sumber pencemaran $\mathrm{NO}_{3}$ dalam air umumnya berasal dari rembesan cubluk, sampah organik hewan, dan air dari tumpukan sampah. Pada titik 3 memiliki kadar $\mathrm{NO}_{3}$ yang serupa dengan titik 1 , meskipun sumber kontaminan yang dapat mencemari air sumur tersebut adalah keberadaan cubluk dengan jarak $6 \mathrm{~m}$. Namun adanya sumber dari kontaminan lain yang dapat memberikan pengaruh keberadaan kandungan nilai $\mathrm{NO}_{3}$ di dalam air tanah. Sumber kontaminan tersebut berupa area pertanian yang menggunakan pupuk yang mengandung Nitrogen berada sekitar \pm 1 $\mathrm{km}$ dari titik pengambilan sampel.

Kondisi yang tidak jauh berbeda juga terjadi pada titik 4 dengan nilai $\mathrm{NO}_{3} 50,6 \mathrm{mg} / \mathrm{l}$, selain keberadaan cubluk yang berjarak $10 \mathrm{~m}$, kandungan $\mathrm{NO}_{3}$ juga dipengaruhi oleh area pertanian yang berjarak $\pm 1,5 \mathrm{~km}$ dari titik pengambilan sampel. Hal tersebut sesuai dengan penelitian yang dilakukan oleh Glanville (1993) dalam Sehadijaya (2014) bahwa kandungan $\mathrm{NO}_{3}$ yang terbawa aliran air tanah mencapai 30 - 500 feet, yaitu sejauh 10 sampai dengan $>150$ meter. Menurut Mancl (1998) dalam Omposunggu (2009) kandungan $\mathrm{NO}_{3}$ dapat terabsorbsi ke dalam kulit apabila kondisi kulit tersebut mengalami luka misalnya luka bakar sehingga semakin memperparah kondisi luka tersebut.

\section{e. Total Coliform}

Berdasarkan Tabel 1. hasil pengujian mikrobiologi menunjukkan bahwa 4 sampel yang diteliti memiliki nilai MPN melebihi baku mutu yang diizinkan berdasarkan baku mutu air Kelas I. Pada sampel 1, 2, 6 dan 7 memiliki nilai MPN sebesar 1100/mL, sedangkan pada sampel 3 memiliki 
nilai MPN sebesar 460/mL, sampel 4 memiliki nilai MPN sebesar 240/mL dan sampel 5 memiliki nilai MPN sebesar 150/mL.

Air tanah (sumur) yang diambil sebagai sampel pada titik 3, 4 dan 5 memiliki jenis konstruksi semen dengan ketinggian bibir sumur masing-masing adalah 0,3 $\mathrm{m}, 0,4 \mathrm{~m}$ dan $0,4 \mathrm{~m}$ dari tanah, serta jarak masing-masing antara sumber pencemar adalah $6 \mathrm{~m}, 10 \mathrm{~m}$ dan $5 \mathrm{~m}$. Sementara sampel pada titik 1, 6 dan 7 memiliki jenis konstruksi sumur yang berasal dari tanah sehingga lebih besar kemungkinan terjadinya rembesan dari sumber pencemar berupa air rembesan cubluk dan kotoran hewan yang berasal dari kandang ternak. Rembesan dari sumber kontaminan tersebut masuk ke dalam sumur melalui dinding sumur dan terakumulasi ke dalam air tanah. Selain itu, sumur tersebut juga tidak dilengkapi dengan tutup dan bibir sumur sehingga air dari sumber kontaminan dapat dengan mudah tercampur ke dalam air tanah di dalam sumur melalui limpasan air hujan.

Pada sampel di titik 2, meskipun memiliki konstruksi sumur yang terbuat dari semen dan memiliki dinding sumur namun jarak antara lokasi sumur dengan cubluk adalah 4 meter dan 6 meter. Kondisi rumah yang terdapat pada titik 2 berdempetan dengan rumah lain yang berada di wilayah tersebut, dan mengakibatkan kondisi cubluk antara 1 rumah ke rumah lainnya relatif dekat sehingga sumur pada titik 2 terletak diantara 2 cubluk. Kondisi tersebut semakin berpotensi menyebabkan banyaknya rembesan polutan dari cubluk yang masuk ke dalam air tanah. Menurut Entjang (2000) menyatakan bahwa kemampuan hidup bakteri patogen selama 3 hari dan perjalanan air dalam tanah 3 meter/hari. Hal tersebut yang memungkinkan bahwa kerapatan jarak antara sumber kontaminan berupa cubluk menjadi faktor utama yang mempengaruhi semakin banyaknya jumlah bakteri patogen dalam saluran air maupun air tanah.

Pada sampel di titik 3, 4 dan 5 memiliki nilai MPN di bawah baku mutu air Kelas I, diduga karena kondisi sumur terbuat dari semen dilengkapi dengan penutup. Sehingga, dapat meminimalisir limpasan air dari sumber pencemar masuk ke dalam air sumur. Selain itu sumur di titik 3 dan 4 memiliki kedalaman sumur mencapai $15 \mathrm{~m}$ dan memiliki kedalaman muka air tanah sampai 3,5 m. Menurut Soeparman dan Suparmin (2002) bahwa muka air tanah serta kondisi tanah di sekitar sumur memiliki pegaruh terhadap kondisi cemaran bakteri Coliform dalam tanah.

\section{f. Power Hydrogen (pH)}

$\mathrm{pH}$ merupakan suatu parameter untuk menentukan kadar asam dan basa dalam suatu perairan. Pengukuran $\mathrm{pH}$ dapat dilakukan dengan menggunakan alat $\mathrm{pH}$ meter yaitu dengan menggunakan prinsip potensiometrik. Nilai pH normal menurut baku mutu air Kelas I memiliki rentang antara 6,5-8,5. Pada hasil pengujian Tabel 1. dapat dilihat bahwa nilai pH pada setiap sampel air tanah yang diukur masih berada pada standar baku mutu air bersih yaitu dengan rentang nilai $\mathrm{pH}$ 6-7 pada setiap sampel.

Sudadi (2003) menyebutkan bahwa apabila air sampel memiliki nilai $\mathrm{pH} \leq 6$ maka air tesebut bersifat asam dan dapat menimbulkan korosi pada pipa sehingga melarutkan unsur-unsur (logam) tertentu yang akan bersifat racun. Sedangkan, apabila $\mathrm{pH} \geq 8,5$ maka akan menyebabkan terbentuknya endapan (kerak) pada pipa sehingga menghasilkan trihalomethane yang bersifat racun.

\section{g. Temperatur (Suhu)}

Temperatur merupakan parameter fisik yang dapat diuji dengan menggunakan alat termometer. Pengukuran dilakukan secara in situ (pengukuran yang dilakukan langsung pada saat pengambilan sampel dan tanpa diawetkan). Temperatur air mempunyai peranan dalam mengatur kehidupan biota perairan, terutama dalam proses metabolisme.Kenaikan temperatur menyebabkan terjadinya peningkatan konsumsi oksigen, namun di lain pihak juga mengakibatkan turunnya kelarutan oksigen dalam air (Effendi, 2003)

Peraturan Pemerintah Republik Indonesia Nomor 28 Tahun 2001 standar baku mutu air Kelas I menyebutkan bahwa kondisi temperatur air yang layak dikonsumsi adalah $\pm 3^{\circ} \mathrm{C}$ yaitu, temperatur yang memiliki nilai sampai dengan $3^{\circ} \mathrm{C}$ dibawah dan diatas temperatur udara disekitarnya. Suripin (2002) menyatakan bahwa temperatur normal yang terdapat di alam (tropis) yaitu sekitar $30^{\circ} \mathrm{C}$. Wilayah Singkawang Utara memiliki temperatur normal rata-rata $27-30^{\circ} \mathrm{C}$ dengan kelembaban $70 \%$. 


\section{Identifikasi Status Mutu Air}

Status mutu air adalah tingkat kondisi mutu air yang menunjukkan kondisi cemar atau kondisi baik pada suatu sumber air dalam waktu tertentu dengan membandingkan dengan baku mutu air yang ditetapkan.

Tabel 2. Hasil Perhitungan Metode Storet Air Tanah di Kecamatan Singkawang Utara

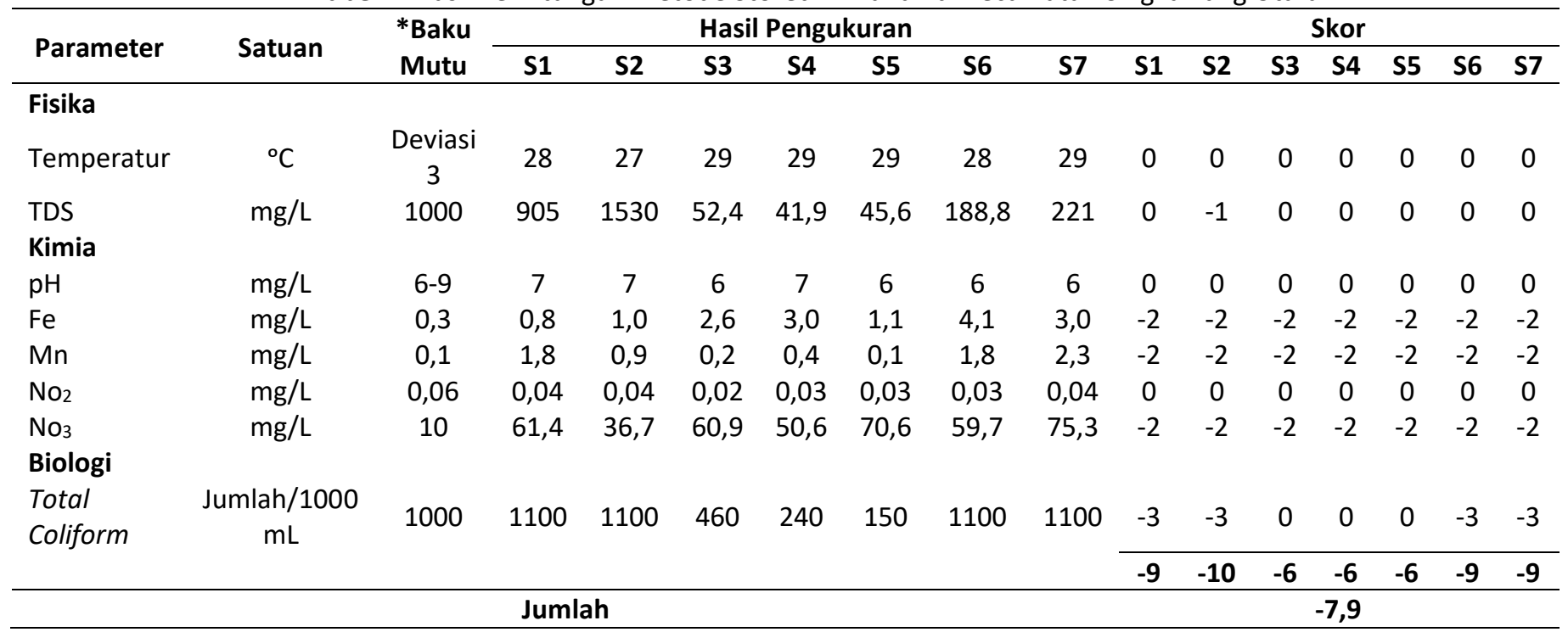

Berdasarkan Tabel 2. nilai status mutu air tanah di Kecamatan Singkawang Utara -7,9 dengan skor masing-masing di setiap titik per kelurahan adalah -10 untuk titik sumur 2 (Kelurahan S. Garam), -9 untuk titik sumur 1 (Kelurahan S. Bulan), 6 (Kelurahan Setapuk Besar) dan 7 (Kelurahan Semelagi Kecil), -6 untuk titik sumur 3 (Kelurahan Naram), 4 (Kelurahan S. Kecil) dan 5 (Kelurahan S.Rasau). Berdasarkan klasifikasi nilai total skor dari US-EPA maka Kecamatan Singkawang Utara termasuk ke dalam Kelas B, yaitu kelas yang memiliki kualitas air Cemar Ringan.

Menurut Mathelmual (2007) kondisi yang mempengaruhi kualitas air tanah di suatu wilayah disebabkan oleh faktor alami dan faktor non alami. Faktor alami dapat berasal dari jenis tanah maupun batuan penyusun yang ada wilayah tersebut dan faktor non alami dapat berasal dari aktivitas yang dilakukan oleh masyarakat disekitar sumur. Berdasarkan data Dinas Pertambangan dan Mineral Provinsi Kalimantan Barat, Singkawang Utara memiliki jenis tanah aluvial dengan batuan penyusun berupa sedimen. Tanah aluvial di Wilayah Singkawang Utara tersusun atas batuan sedimen dengan topografi datar. Aluvial adalah tanah yang dibentuk dari lumpur sungai yang mengendap di dataran rendah memiliki karakteristik berawarna kelabu sampai kecoklatan dengan tekstur tanah liat atau berpasir (kandungan pasir sekitar $50 \%$ ) dan tingkat produktifitas tanahnya antara rendah sampai tinggi. Unsur-unsur yang dominan pada air tanah di dataran aluvial adalah unsur $\mathrm{Ca}, \mathrm{Mn}, \mathrm{Si}$, dan Fe (Karmono dan Cahyo, 1978 dalam Hariyanto, 2015).

Menurut Baver (1962) dalam Edial (2008) permeabilitas tanah merupakan kecepatan bergeraknya cairan pada suatu media berpori dalam keadaan jenuh. Semakin besr nilai porositas (tekstur tanah) semakin kecil permeabilitasnya. Jenis tanah aluvial memiliki tekstur lempung dengan porositas 45-50\%, pasir dengan porositas 30-35 \%, dan kerikil 25-30\%. Tanah endapan dengan tekstur lumpur memiliki porositas 55 - $65 \%$. Tanah endapan lumpur berasal dari tanah hasil pelapukan endapan aluvial yang belum sempurna. Kondisi lain yang memungkinkan munculnya pencemaran terhadap sampel air tanah di Kecamatan Singkawang Utara disebabkan oleh faktor non alami. Kondisi tersebut dapat berasal dari rembesan air cubluk, kandang ternak, selokan dan timbunan sampah yang terdapat di sekitar sumur. Jarak antara sumber pencemar terhadap sumur dapat dilihat pada Tabel 3. 
Tabel 3. Jarak Sumur Terhadap Sumber Pencemar

\begin{tabular}{cccccc}
\hline \multirow{2}{*}{$\begin{array}{c}\text { Titik } \\
\text { Sampel }\end{array}$} & Cubluk & $\begin{array}{c}\text { Kandang } \\
\text { Ternak }\end{array}$ & Selokan & $\begin{array}{c}\text { Timbunan } \\
\text { Sampah }\end{array}$ & $\begin{array}{c}\text { Area } \\
\text { Pertanian }\end{array}$ \\
\cline { 2 - 6 } & 8 & - & - & 4 & - \\
2 & $4 \& 6$ & - & 3,5 & - & - \\
3 & 6 & - & - & - & 1000 \\
4 & 10 & - & - & - & 1500 \\
5 & 5 & 1 & - & - & - \\
6 & 8 & - & 6,8 & - & - \\
7 & 8,5 & 4 & - & - & - \\
\hline
\end{tabular}

Keterangan : ${ }^{*} \mathrm{~m}=$ meter

\section{Upaya Pengelolaan}

Adapun upaya yang dapat dilakukan dalam pengelolaan kualitas air tanah khususnya sumur dangkal, di Kecamatan Singkawang Utara adalah :

a. Diharapkan agar pemerintah dan masyarakat setempat menjaga sanitasi lingkungan di sekitar sumur dengan tidak melakukan aktivitas yang dapat menyebabkan masuknya pencemar ke dalam air sumur.

b. Perlu diadakannya pengujian kualitas air secara berkala agar dapat diketahui tingkat kualitas dari air tersebut. Menurut SNI 6989.58 : 2008 tentang Air dan Air Limbah bahwa kualitas air tanah umumnya dilakukan pengujian minimal sekitar 3 bulan sekali.

c. Agar masyarakat dapat memperhatikan strategi maupun cara pembuatan sumur agar sesuai dengan Standar Nasional Indonesia (SNI) 03-2916-1992 tentang Spesifikasi Sumur Gali untuk Sumber Air Bersih, yaitu membuat sumur dengan jenis konstruksi semen/bata, memberi dinding semen pada bibir sumur, memperhitungkan jarak sumur yaitu lebih dari $11 \mathrm{~m}$ terhadap sumber pencemar.

d. Selain itu upaya yang dapat dilakukan adalah dengan melakukan pengolahan sebelum menggunakan air tersebut. Pengolahan umum yang dapat dilakukan baik secara fisika maupun kimia, yaitu :

$>$ Koagulasi (Penggumpalan)

Pengolahan dengan cara koagulasi merupakan pengolahan yang dilakukan secara kimia dengan membubuhkan bahan koagulan. Bahan koagulan tersebut misalnya aluminium sulfat (tawas), PAC ke dalam air. Koagulan tersebut akan mengikat unsur tertentu seperti Besi dan Mangan membentuk (flok) kemudian mengendap. Koagulan tersebut berfungsi untuk mengurangi kadar logam yang terdapat dalam air tanah, selain itu juga dapat mengurangi kadar nitrit, nitrat dan bakteri patogen yang terdapat di dalam air.

> Filtrasi (Penyaringan)

Pengolahan dengan menggunakan filtrasi atau secara fisik yaitu melakukan penyaringan dengan memanfaatkan media-media seperti zeolit, karbon aktif, maupun pasir. Menurut Purwonugroho (2013) media zeolit dan karbon aktif dapat menurunkan kadar Besi, Mangan dan Nitrat yang terkandung dalam air.

\section{- KESIMPULAN}

Berdasarkan hasil, analisis dan pembahasan, maka dapat disimpulkan bahwa :

1. Kualitas air tanah di Kecamatan Singkawang Utara yang melebihi baku mutu air bersih Kelas I menurut Peraturan Pemerintah Republik Indonesia Nomor 82 Tahun 2001 adalah TDS, Fe, $\mathrm{Mn}, \mathrm{NO}_{3}^{-}$dan Total Coliform.. Tingginya nilai Fe dan Mn pada sampel air disebabkan oleh faktor alami berdasarkan jenis tanah wilayah setempat. Tingginya nilai TDS, $\mathrm{NO}_{3}$ dan Total Coliform pada sampel disebabkan oleh faktor non alami yang berasal dari kondisi dan aktivitas di sekitar sumur (dekatnya jarak sumur terhadap cubluk, kandang ternak, tumpukan sampah dan area pertanian yang menggunakan pupuk Nitrogen).

2. Status mutu air tanah di Kecamatan Singkawang Utara tergolong dalam tercemar ringan dengan nilai $-7,2$. 
3. Upaya yang dapat dilakukan dalam mengelola kualitas air tanah di Kecamatan Singkawang Utara adalah dengan melakukan pemantauan kualitas air secara berkala, memperhatikan aspek sanitasi dari segi pembuatan sumur maupun dari lingkungan di sekitar sumur, dan melakukan pengolahan sebelum menggunakan air tersebut.

\section{- UCAPAN TERIMAKASIH}

Penulis mengucapkan terimakasih kepada Camat dan Lurah Singkawang Utara yang telah memberikan peizinan di Wilayah Singkawang Utara untuk dijadikan lokasi pelaksanaan penelitian ini. Penulis juga mengucapkan banyak terimakasih kepada Bapak Kiki Prio Utomo, S.T., M.Sc sebagai dosen pembimbing utama dan Ibu Dian Rahayu Jati, S.T.,M.Si sebagai dosen pembimbing kedua serta Ibu Ulli Kadaria, S.T., M.T dan Bapak Hendri Sutrisno, S.T., M.T sebagai dosen penguji utama dan kedua yang telah banyak memberikan masukan selama pengerjaan skripsi dan jurnal ini.

\section{- DAFTAR PUSTAKA}

Edial, H. dan Triyatno. 2008. Analisa Karakteristik Tanah Wilayah Banjir Di Kecamatan Koto Tangah Padang. Jurusan Geografi Fakultas Ilmu-Ilmu Sosial Universitas Negeri Padang

Effendi, H. 2003. Telaah Kualitas Air bagi Pengelolaan Sumber Daya dan Lingkungan Perairan. Cetakan Kelima. Yogjakarta : Kanisius.

Entjang, 2000. Ilmu Kesehatan Masyarakat, Bandung. PT. Citra Aditya Bakti

Hariyanto, B. 2015. Studi Kimia Air Tanah Dangkal Untuk Deteksi Intrusi Air Laut Di Pesisir Kabupaten Rembang Propinsi Jawa Tengah Tahun 2014 Dan Implementasinya Untuk Pembelajaran Geografi Di Sma. Program Pascasarjana Kependidikan Fakultas Keguruan Ilmu Kependidikan Universitas Sebelas Maret Surakarta

Jatmiko, A. 2007. Hubungan Kualitas Air Selokan Ngenden Desa Gumpang Kartasura Sukoharjo Dengan Air Sumur Penduduk Sekitar. Jurusan Biologi Fakultas Matematika Dan IImu Pengetahuan Alam Universitas Sebelas Maret. Surakarta

Kementrian Lingkungan Hidup. 2003. Keputusan Menteri Lingkungan Hidup, No. 115 Tahun 2003 Tentang Pedoman Penentuan Status Mutu Air Menteri Negara Lingkungan Hidup. Jakarta.

Matahelumual, B,.C., 2007. Penentuan Status Mutu Air dengan Sistem STORET di Kecamatan Bantar Gebang. Pusat Lingkungan Geologi. Diponegoro. Bandung.

Ompusunggu, H., 2009. Analisa Kandungan Nitrat Air Sumur Gali Masyarakat Di Sekitar Tempat Pembuangan Akhir. (TPA) Sampah Di Desa Namo Bintang Kecamatan Pancur Batu Kabupaten Deli Serdang. Fakultas Kesehatan Masyarakat Universitas Sumatera Utara. Medan.

Peraturan Pemerintah No. 82 Tahun 2001 Tentang Pengelolaan Kualitas Air dan Pengendalian Pencemaran Air. Jakarta.

Purwonugroho. 2013. Keefektifan Kombinasi Media Filter Zeolit Dan Karbon Aktif Dalam Menurunkan Kadar Besi (Fe) Dan Mangan (Mn) Pada Air Sumur. Program Studi Kesehatan Masyarakat Fakultas IImu Kesehatan Universitas Muhammadiyah Surakarta.

Sehadijaya, N. 2014. Perbandingan Kandungan Nitrat ( $\left.\mathrm{No}_{3}\right)$ Pada Air Sumur Gali Masyarakat Di Kelurahan Padengo Kecamatan Kabila. Jurusan Kesehatan Masyarakat, Fakultas IImuilmu Kesehatan dan Keolahragaan, Universitas Negeri Gorontalo.

SNI 01-2332.1-2006 Tentang Penentuan Coliform dan Eschericia Coli

SNI 03-2916-1992 Tentang Spesifikasi Sumur Gali untuk Sumber Air Bersih.

SNI 6989.58 : 2008 Tentang Air dan Air Limbah - Bagian 58 : Metode Pengambilan Contoh Air Tanah.

Soeparman \& Suparmin. 2002. Pembuangan Tinja \& Limbah Cair. Jakarta : EGC

Sudadi, P. 2003. Penentuan Kualitas Air Tanah Melalui Analisis Kimia Terpilih. Sub Direktorat Pendayagunaan Air Tanah, DTLGKP. Bandung.

Sutton. 2010. The Most Probable Number Method and Its Uses in Enumeration, Qualification, and Validation 